\title{
An investigation into features of news web-sites in Bangladesh
}

\author{
Md. Mashihur Rahman \\ Rajshahi University, Bangladesh
}

Md. Aminul Islam

Varendra University, Bangladesh

DOI: $10.30547 /$ worldofmedia.2.2018.3

\begin{abstract}
News industry in the world, as well as in Bangladesh, is experiencing massive transformation due to innovation and availability of different information and communication technologies. The production, consumption and revenue sources are being dramatically changed. News outlets are struggling to keep pace with the constant changes and adaptations as it demands multiple investments in technologies and skills. Online sources are developing multiple features in presenting content utilizing various options and opportunities brought about by technology. This article investigates the web-sites of 35 news outlets, both online only and online platforms of traditional newspapers and TV in Bangladesh. It explores the features that empower both news producers and consumers in terms of designing platforms, delivering content, and freedom in consumption. The features include scope for customization, interactivity, embedding of multimedia, availability of user-friendly services and additional delivery channels both on homepage and story pages. It employs content analysis method. Analysis of the data shows that limited number of web features are available on the selected news sites with major weakness in presenting multimedia content, scope for customization and greater interactivity.
\end{abstract}

\section{Keywords}

News industry, online journalism, hypertextuality, interactivity, multimedia, Bangladesh.

Corresponding author:

Md. Aminul Islam, Department of Journalism, Communication and Media Studies, Varendra University, 529/1, Kazla, Motihar, Rajshahi-6204, Rajshahi, Bangladesh Email: aminul@vu.edu.bd/aminul.vu@gmail.com 


\section{Introduction}

Propelled by innovative communication technologies, the profession of journalism, as well as the whole media ecology, is going through enormous transformations. The changes include content production, delivery and consumption process, revenue and business models (MacNamara, 2010), the role of journalists (Singer, 2006), the relationship between a journalist and a reader, and audiences' loyalty to a news organization (Tandoc, 2014). The driving forces of the changes are the Internet and smartphones. Beginning in the latter half of the 1990s, most of the scholarships on online journalism focus on exploring online journalism as breaking news journalism (Saltzis, 2012), and interactivity (Chung, 2008; Stroud et al., 2015). Mark Deuze (2001) identified three key characteristics on online journalism at main stream news outlets. Those are hypertextuality, interactivity, multimediality.

Tanjev Schultz (2006) investigated the interactive options in online journalism. By analyzing content of 100 newspapers in the USA, the researcher concluded that only few interactive options are used. Most of the options are not functional, rather those are symbolically used. Meanwhile, Hans Beyers (2006) argued that a good news site must have 16 fundamental components of multimedia, interactivity, hypertext, and immediacy. The components include photo gallery, audio (such as interviews or music), video (such as interviews, reports), interactive graphs, discussion boards, chat, polls, games, quiz, search feature, SMS services, availability of content that can be read on a mobile phone, availability of similar content PDF version, use of internal and external hyperlinks, e-letters and breaking news.

Deborah S. Chung (2008) identified four categories of features that promote interactivity. Under the categories the features include submit stories' function, submit photos' function, submit news tip, reporter/editor e-mail links, lettersto-editor, customized topics, customized headlines, search feature, e-mail updates/alerts, message boards, chat functions, Q\&A (live chats), audio files and video files. The researcher, however, argued that online audiences do not use all the interactive features extensively. Using content analysis methods, Ali Rafeeq (2014) investigated the interactive features of the three mainstream news web-sites in the Maldives. The researcher found that the news web-sites did not fully utilize and enhance interactive features.

Most of the studies on online journalism and new media ecology have been conducted in Western perspective. Very little research investigated this issue from Bangladesh context. Investigating 28 newspapers in Bangladesh, Mashihur Rahman (2008) found that the news outlets provide limited level of interactivity which allows readers to be more engaged and empowered in the news process. 
However, the researcher mainly focused on interactive options only on the homepage of the news media.

To fill the gap, as there is no research on the topic with a comprehensive approach combining web feature on homepage and story page in the context of Bangladesh, this study investigated web features of 35 news outlets, both online only and online platforms of traditional newspapers and television in the country. It explored the features that empower both news producers and consumers in terms of designing platforms, delivering content, and freedom in consumption.

\section{Methodology \\ Sample selection}

Bangladesh's media industry comprises of news outlets of print, television and radio. Leading news outlets have presence small size online and operate from the capital city of Dhaka. With the availability of the Internet, very small on top news sites in a globally popular online news outlets with limited resources and coverage are mushrooming across the country, which is a recent phenomenon. However, news outlets which operate from Dhaka dominate the information ecology of the country. According to a report of the Department of Film and Publication (DFP), the state body for registration and monitoring media industry under the Ministry of Information in Bangladesh, there are 1,213 registered daily newspapers in the country of which 483 operates from Dhaka. All of the 45 private television channels operate from the capital city. Up until 2017, the Ministry of Information did not have any mechanism to register online platforms. However, a process of registering online news platforms has recently been initiated by the Ministry, and it has received a total of 2018 applications from all over the country (BBC Bangla report January 2018).

This study investigates features of both homepage and story page of top 35 news outlets based in Dhaka. The outlets were selected purposively as no authentic database and listing of news media were found in the country. Even the researchers found no data on top news sites in a globally popular web rating site, Alexa (www.alexa.com). So, the outlets on top news sites in a globally popular were selected on the basis of their perceived popularity and reach in the country. Moreover, the researchers used insights, observations, informal interviews with media practitioners, and consultation with academics and researchers to select the news outlets for the study. To make the sample representative, both online only, web version of traditional newspapers and television were included in the study. Languages of the outlets were taken into account by incorporation of Bangla, English and the outlets with both Bangla and English versions. 


\section{Data collection and analysis}

Data were collected on the features by accessing to both homepage and story pages of the selected news sites. The features on homepage were divided in five categories - customization (page layout, page format, other language edition, and content selection), interactivity (online live chat, contact us, email by-line, online poll, blogging, message boards, forums, provide new tips), multimedia (video clippings, audio clippings, vodcast, podcast, slide shows, photos and graphics), user-friendly services (news alerts, list of top stories, e-commerce, search engines, archives, online translations, podcast, vodcast, and web specials), additional delivery channels (mobile, email newsletters, and RSS).

Meanwhile, the story page features were divided in six categories which include customization (text size, column format, story format), interactivity (byline email and provide news tips), multimedia in the story (video clippings, audio clippings, slide shows, photos, graphics), multimedia next to the story (video clippings, audio clippings, slide shows, photos, graphics, vodcast, podcast), user-friendly services (translate the story, listen to the story, blog the story, email the story, comment on the story, contribute readers' version of the story) and hypertext (hypertext in the story and hypertext to the story).

Simple descriptive statistical methods were performed to generate insight into the collected data. The availability of the features is presented in number and percentages in groups and tables. For media platform type and language of news outlets, cross tab method has been performed.

\section{Overall analysis of web features Web features on the homepage}

Results on customization, interactivity, multimedia, user-friendly services, and additional delivery channel options on the homepage are presented in Table 1 below.

Customization means allowing audience control over the content, layout and display, category, index letting users make their own selections about what they want to see or set preferences for how information is organized or displayed. It can enhance user experience because it allows users' freedom in their interaction. Customization might allow users to track contents of their interests, regions. Moreover, users may be facilitated to create and maintain a list of pages allowing users' control of getting exactly what they want and sometimes how they want. Users can rearrange the page content in terms of the language, font size, and content categories.

The results indicate that online journalism in Bangladesh is passing a nascent period in terms of availability of interactive features on the web-sites 
of newspapers. Although none of the sample online newspapers provide options on the homepage for customization of page layout, page format and content, $14(40 \%)$ of observed news outlets allow readers to consume their content in a language other than Bangla, and the second language is English. Meanwhile, 28 (80\%) news outlets have options for customization of the content by the index type. On the other hand, 15 (42.9\%) news outlets allow their readers to customize the content in terms of geographical location of the news.

Interactivity is one of the key features of online journalism. Availability of multiple options include online live chat, contact us, email by-line, online poll, blogging, message boards, forums, provide news tips and search options are some of the indicators of an interactive news site. Results indicate that online news outlets in Bangladesh use very few interactive features on their homepages. Most used interactive features are contact us - 32 (91.4\%), online poll - 12 (34.3.70\%), and search option - 30 (85.07\%).

Today, journalism is not merely a textual and pictorial representation. It is now multimodal. A news story or news package is created with any combination of text, image, audio, video and graphics. Analysis of the data in Table 1 shows that news outlets in the country mainly use a combination of text, video clippings, and photographs. In some cases, slide shows are made by using photographs. High end graphics are not used to explain any news or event. Rather, mainly Google map is used as a graphical element. Only $20(57.10 \%)$ news outlets embed video clippings in their homepages. Meanwhile, 18 (51.40\%) news outlets provide slide shows, 34 (97.1\%) provide photos, and 24 (68.60\%) provide graphical elements in their content on homepages.

In recent years, news organizations around the globe have increased some user-friendly services enabling users choosing and getting information and making its effective use with comfort and in a desired way. News alerts, list of top stories, list of popular stories, list of most viewed stories, list of most emailed stories, archives, online translation service, save story, update time are some of these services. They have given more freedom in consuming news than ever in the history of journalism. But all the options are not available in most of the sample news sites. The results show that options for archiving news content are most available (91.70\%) in the selected news sites, which means that 29 news sites archive their content. However, most of the news sites provided the following options: list of top stories - 25 (58.30\%), list popular stories - 25 (66.70\%), and most viewed stories -22 (83.30\%). On the other hand, none of the sampled news sites provide online translation service and save story folders on their homepage.

In the traditional way, news distribution is relatively straightforward. Printed in a press at a certain time, then transported to newspaper agents or 
selling outlets, from there picked by newspaper hawkers, then distributed or delivered to readers. Meanwhile, in case of broadcast medium, telecasting news at a certain time, and watched or listened by audiences. But news distribution in a new media world is completely a new process. Today, news reaches the audience through multiple channels, and it is made possible by technologies like social media platforms (mainly Facebook), mobile phones, various apps, email newsletters and RSS feeds. Analysis of the results shows that social media platforms mostly use additional delivery channel in Bangladeshi news media followed by breaking news options, mobile phone app, mobile phone, RSS feed and newsletter. 29 (82.20\%) of the sample news outlets distribute their news through social media platforms, $14(40.00 \%)$ through mobile phone apps of different operating systems. Meanwhile, 19 (54.30\%) reach their audiences through braking news option on their homepage and 4 (11.4\%) through RSS feeds. Surprisingly, only one (2.90\%) news outlet uses email newsletter as their news delivery channel.

Table 1

Availability of web features of different categories on the homepage

\begin{tabular}{|c|c|c|c|}
\hline \multirow{2}{*}{ Categories } & \multirow{2}{*}{ Web features } & \multicolumn{2}{|c|}{$\begin{array}{c}\text { Total observed news } \\
\text { outlets } / \mathrm{N}=35\end{array}$} \\
\hline & & Yes & No \\
\hline \multirow[t]{6}{*}{ Customization } & Page layout & 0 & 35 \\
\hline & Page format & 0 & 35 \\
\hline & Other language edition & 14 & 21 \\
\hline & Content & 0 & 100 \\
\hline & Index by type & 28 & 7 \\
\hline & Index by place & 15 & 20 \\
\hline \multirow[t]{9}{*}{ Interactivity } & Online live chat & 0 & 35 \\
\hline & Contact us & 32 & 3 \\
\hline & Email by-line & 0 & 35 \\
\hline & Online poll & 12 & 23 \\
\hline & Blogging & 0 & 35 \\
\hline & Message boards & 0 & 35 \\
\hline & Forums & 0 & 35 \\
\hline & Provide news tips & 2 & 33 \\
\hline & Search option & 30 & 5 \\
\hline
\end{tabular}




\begin{tabular}{|l|l|c|c|}
\hline \multirow{4}{*}{ Multimedia } & Video clippings & 20 & 15 \\
\cline { 2 - 4 } & Audio clippings & 3 & 32 \\
\cline { 2 - 4 } & Vodcast & 0 & 35 \\
\cline { 2 - 4 } & Podcast & 0 & 35 \\
\cline { 2 - 4 } & Slide shows & 18 & 17 \\
\cline { 2 - 4 } & Photos & 34 & 1 \\
\cline { 2 - 4 } & Graphics & 24 & 11 \\
\hline User-friendly services & News alerts & 0 & 35 \\
\cline { 2 - 4 } & List of top stories & 25 & 10 \\
\cline { 2 - 4 } & List popular stories & 25 & 10 \\
\cline { 2 - 4 } & List of most viewed stories & 22 & 13 \\
\cline { 2 - 4 } & List of most emailed stories & 1 & 34 \\
\cline { 2 - 4 } & Archives & 29 & 6 \\
\cline { 2 - 4 } & Online translation service & 0 & 35 \\
\cline { 2 - 4 } & Save story folders & 0 & 35 \\
\cline { 2 - 4 } & Story update time & 28 & 7 \\
\hline \multirow{4}{*}{$\begin{array}{l}\text { Additional } \\
\text { delivery channel }\end{array}$} & Mobile phone & 5 & 30 \\
\cline { 2 - 4 } & Newsletter & 1 & 34 \\
\cline { 2 - 4 } & RSS & 29 & 6 \\
\cline { 2 - 4 } & Apps & & 21 \\
\cline { 2 - 4 } & Breaking news options & 19 & 16 \\
\cline { 2 - 4 } & Social media & & 6 \\
\hline
\end{tabular}

\section{Web features on the story page}

News story is not merely a package of information, facts, figures or images. Rather, it is a consumable product with combination of multiple elements. Audiences want to consume it with their choice and freedom. Options for text customization, interactivity, multimedia in the story, multimedia next to the story, user-friendly services and hypertext give readers the choice and freedom. Results on web features on story pages are presented in Table 2 .

Scope for customization can allow readers more freedom to consume content. For convenience, readers sometimes want to increase or decrease sizes of the texts they read, change the format of the column and story format. This opportunity engages the audience in a more immersive manner. But, the results of the study reveal that Bangladeshi news media give relatively less freedom to their audiences. Only 9 (25.70\%) sample news outlets allow their readers to customize the sizes of texts. While, 
none of the news outlets give scope for customizing the column and story formats.

Today, audiences are not passive consumers of news, and the relation between journalists, news media and the audience are not linear. Rather the relation is two-dimensional and the audiences want to be engaged in the news process. The two-dimensional relation and engagement are created through availability of combination of options in news story. The options include by-line email to the reporter, scope for providing news tips by readers, integrating multiple social media platforms and delivering news through the platforms on a regular basis, scope for printing the story if the reader feels the need for it. Most importantly, an effective interaction takes place in the news process when readers can leave comments on a certain story, and they can express their views and arguments on the story. The results of the study (Table 2) show that 33 (91.40\%) of the sample news outlets allow their audiences to print the stories. But very few dialogues happen between a certain reporter and audiences through email as $33(94.28 \%)$ news outlets do not have options for by-line email, meaning that only two $(5.70 \%)$ news outlets allow their readers to communicate with their reporters. Moreover, readers cannot provide any news tip as this scope is not given by any of the news outlets. However, 26 (54.30\%) of the news outlets allow their audiences to comment on the news stories. The results indicate that Bangladeshi news media are much more advanced in interacting with their audiences through social media platforms. The analysis of the web features shows that $33(94.30 \%)$ news outlets use social media platforms as a way of audience engagement.

News is all about multi-sensory communication today. To make it an effective one, news media incorporate multimedia elements in news stories. The multimedia elements include video clippings, audio clippings, slide shows, photos, graphics, vodcast and podcast. Results show that photos - 35 (100\%) and graphics - 25 (71.4\%) - are mostly used multimedia elements in Bangladesh news media. Meanwhile, video clippings, audio clippings, slide shows are less used in news stories respectively. On the other hand, very few numbers of news outlets use multimedia content next to the story.

In order to increase revenue, news outlets around the world are striving for attracting audiences by providing diverse user-friendly services. The services include scope for translating story into another convenient language, listening to the whole story, blogging the story, emailing the story, rating the story, saving the story, leaving comment on the story, incorporating readers' version of the story, printing the story, and the time of the upload and update the story. The results show that printing options $-31(88.60 \%)$, update time $-31(88.60 \%)$, 
comment on the story - 19 (54.30\%) and email the story - 11 (31.40\%) are the most used user-friendly services in Bangladeshi news media. Only three news outlets allow their audience to rate the story. Meanwhile, none of the sample news outlets have the options for translating the story, listening to the story by using an audio player or any other device, blogging the story and adding readers' version to the story. But media users respond to news stories through comments option.

Hypertextuality is one of the most important aspects of news production and consumption in online environment today. It is used to provide context, background, and provide value to the news story. It helps the audience to make sense of a certain issue or event more clearly as it takes the readers to the relevant and deeper meaning of the story. Hypertexts are given in the story and next to the story. Only three $(8.60 \%)$ of total sample news outlets incorporate hypertext to a news story. Interestingly, four (11.40\%) news outlets incorporate hypertext next to the story which allows readers to make sense of the context and background of any issue or event.

Table 2

Availability of web features of different categories on the story page

\begin{tabular}{|l|l|c|c|}
\hline \multirow{3}{*}{ Categories } & \multicolumn{1}{|c|}{ Web features } & Total observed news outlets /N=35 \\
\cline { 2 - 4 } & & Yes & No \\
\hline \multirow{4}{*}{ Customization } & Text size & 9 & 26 \\
\cline { 2 - 4 } & Column format & 0 & 35 \\
\cline { 2 - 4 } & Story format & 0 & 35 \\
\hline Interactivity & By-line email & 2 & 33 \\
\cline { 2 - 4 } & Provide news tips & 0 & 35 \\
\cline { 2 - 4 } & Social media integration & 33 & 2 \\
\cline { 2 - 4 } & Print the story & 33 & 3 \\
\cline { 2 - 4 } Multimedia & Comment on the story & 26 & 32 \\
\hline in the story & Video clippings & 4 & 26 \\
\cline { 2 - 4 } & Audio clippings & 3 & 0 \\
\cline { 2 - 4 } & Slide shows & 9 & 10 \\
\cline { 2 - 4 } & Photos & 35 & 32 \\
\cline { 2 - 4 } & Graphics & 25 & \\
\hline
\end{tabular}




\begin{tabular}{|c|c|c|c|}
\hline \multirow{7}{*}{$\begin{array}{l}\text { Multimedia next } \\
\text { to the story }\end{array}$} & Video clippings & 4 & 31 \\
\hline & Audio clippings & 0 & 35 \\
\hline & Slide shows & 4 & 31 \\
\hline & Photos & 7 & 28 \\
\hline & Graphics & 4 & 31 \\
\hline & Vodcast & 0 & 35 \\
\hline & Podcast & 0 & 35 \\
\hline \multirow{10}{*}{$\begin{array}{l}\text { User-friendly } \\
\text { services }\end{array}$} & Translate the story & 0 & 35 \\
\hline & Listen the story & 0 & 35 \\
\hline & Blog the story & 0 & 35 \\
\hline & Email the story & 11 & 24 \\
\hline & Rate the story & 0 & 35 \\
\hline & Save the story & 3 & 32 \\
\hline & Comment on the story & 19 & 16 \\
\hline & \begin{tabular}{|l|} 
Contribute readers' \\
version of the story \\
\end{tabular} & 0 & 35 \\
\hline & Print the story & 31 & 4 \\
\hline & Update time & 31 & 4 \\
\hline \multirow[t]{2}{*}{ Hypertext } & Hypertext in the story & 3 & 32 \\
\hline & Hypertext to the story & 4 & 31 \\
\hline
\end{tabular}

\section{Comparison of media specific web features}

This section presents the results on media of two categories - media type by platform (online only, online version of a traditional newspaper and online platform of TV) and language (Bangla only, English only and both Bangla and English). However, only results of some particular features are considered here.

An opinion poll, often conducted by news media, is an important indicator to understand multiple social and political dynamics of a country (Anstead \& O'Loughlin, 2014). The Internet has made possible to conduct such polls in a more engaging, participatory, easy and timely manner. Audience of online news outlets can respond to any social and political issues through such polls conveniently. On the other hand, the outlets can use the poll as strong audience engagement technique which can lead to increased revenue of the news outlets. The analysis of data (Table 3) shows that only 9 (34.29\%) news outlets provide the audience with options to participate in such opinion polls. Two (5.71\%) of the outlets are online only, and seven (28.57\%) are the online platforms of newspapers. Meanwhile, none of the online platforms of TV have the option for opinion polls on their web-sites. The results yield a contrasting scenario as online only news outlets far lag behind the online platform of traditional newspapers in this case. Similar insights can be found in the case of news outlets 
of language category. In case of opinion polls, Bangla news outlets are far ahead of English and Bilingual outlets. Data indicate that eight (22.86\%) news outlets which deliver content in Bangla have options for opinion polls.

Table 3

Online poll (Total observed news sites 35)

\begin{tabular}{|c|c|c|c|c|c|c|c|}
\hline \multirow{2}{*}{$\begin{array}{c}\text { Types } \\
\text { of news platform }\end{array}$} & \multicolumn{3}{|c|}{ Online poll } & \multirow{2}{*}{$\begin{array}{c}\text { Language } \\
\text { of news outlet }\end{array}$} & \multicolumn{3}{|c|}{ Online poll } \\
\hline & Yes & No & Total & & Yes & No & Total \\
\hline Online only & 2 & 7 & 9 & Bangla only & 8 & 12 & 20 \\
\hline $\begin{array}{l}\text { Online platform } \\
\text { of newspaper }\end{array}$ & 10 & 14 & 24 & English only & 1 & 3 & 4 \\
\hline $\begin{array}{l}\text { Online platform } \\
\text { of TV }\end{array}$ & 0 & 2 & 2 & $\begin{array}{l}\text { Both Bangla } \\
\text { and English }\end{array}$ & 3 & 8 & 11 \\
\hline Total & 12 & 23 & 35 & Total & 12 & 23 & 35 \\
\hline
\end{tabular}

\section{Hypertext}

One of the basic aspects of the web is the hypertext (De Maeyer, 2012). In online journalism, it offers a broader scope for good for storytelling and keeping the audience more informed. Good storytelling requires multiple sources of information. Providing links to a certain word, idea or concept adds context, explains details and provides depth to the story. Thus, it enables greater transparency, credibility, interactivity, readability, information-seeking and connectivity (De Maeyer, 2012; Borah, 2014). Analysis of data (Table 4) indicates that news outlets in Bangladesh do not capitalize the immense opportunity of good storytelling brought about by the Internet as a poor number of news outlets provide links to their stories. Only three (8.57\%) news outlets provide hypertext in the story and four $(11.43 \%)$ next to the story. Only one $(2.86 \%)$ online news outlet provides hypertext in the story. Interestingly, online platforms of traditional newspapers are ahead of online only platforms as two (5.71\%) of the platforms provide links in the story and three $(8.57 \%)$ next to the story. Meanwhile, none of the Bangla language news outlets provide links in the story and next to the story. Only three (8.57\%) news outlets which are bilingual provide a link in the story and next to the story. 
Availability of hypertexts both in and next to the story by type and language of news outlets

(Total observed news sites, $\mathrm{N}=35$ )

\begin{tabular}{|c|c|c|c|c|c|c|c|c|c|c|c|c|c|}
\hline \multirow[t]{2}{*}{$\begin{array}{l}\text { Types news } \\
\text { platform }\end{array}$} & \multicolumn{3}{|c|}{$\begin{array}{l}\text { Hypertext } \\
\text { in the story }\end{array}$} & \multicolumn{3}{|c|}{$\begin{array}{c}\text { Hypertext } \\
\text { next } \\
\text { to the story }\end{array}$} & \multirow[t]{2}{*}{$\begin{array}{c}\text { Language } \\
\text { of news } \\
\text { outlet }\end{array}$} & \multicolumn{3}{|c|}{$\begin{array}{l}\text { Hypertext } \\
\text { in the story }\end{array}$} & \multicolumn{3}{|c|}{$\begin{array}{c}\text { Hypertext } \\
\text { next } \\
\text { to the story }\end{array}$} \\
\hline & Yes & No & Total & Yes & No & Total & & Yes & No & Total & Yes & No & Total \\
\hline Online Only & 1 & 8 & 9 & 1 & 8 & 9 & $\begin{array}{l}\text { Bangla } \\
\text { only }\end{array}$ & 0 & 20 & 20 & 0 & 20 & 20 \\
\hline $\begin{array}{l}\text { Online } \\
\text { Platform of } \\
\text { Newspaper }\end{array}$ & 2 & 22 & 24 & 3 & 21 & 24 & $\begin{array}{l}\text { English } \\
\text { Only }\end{array}$ & 0 & 4 & 4 & 1 & 3 & 4 \\
\hline $\begin{array}{l}\text { Online } \\
\text { platform } \\
\text { of TV }\end{array}$ & 0 & 2 & 2 & 0 & 2 & 2 & \begin{tabular}{|l} 
Both \\
Bangla \\
and \\
English \\
\end{tabular} & 3 & 8 & 11 & 3 & 8 & 11 \\
\hline Total & 3 & 32 & 35 & 4 & 31 & 35 & Total & 3 & 32 & 35 & 4 & 31 & 35 \\
\hline
\end{tabular}

\section{Additional delivery channel}

Multiple communication technologies and social media platforms are changing the production, distribution and discovery of news. Technology has created options to deliver information in a variety of ways these days. Delivering digital content does not depend only on Web. Audiences want to access information from their smartphone, tablet, laptop computer or another mobile device. Today, publishing of and accessing to information is all about real time - at any time and from anywhere. On the other hand, news outlets are fiercely fighting to maximize their revenue by reaching far, wide and diverse audiences. Most of the Bangladeshi news outlets use six types of channels in addition to the main web-site to deliver the content. The channels include mobile phones, newsletters, breaking news options, mobile applications, social media and RSS. The analysis of data shows (Table 5) that five (14.29\%) news outlets deliver their content through mobile phone text messages, three $(8.57 \%)$ of them are online only and two (5.71\%) are online platforms of traditional newspapers. Meanwhile, 29 (82.86\%) news outlets reach their audience through social media platforms, mainly Facebook. 18 (51.43\%) outlets are online platforms of traditional newspapers and $9(25.71 \%)$ are online only news outlets. This figure indicates that online only platforms far lag behind traditional newspapers in 
social media as their delivery channel. Mobile apps are the leading platform of news distribution, which stands at 14 (40.00\%). Among the news outlets which use apps as their news delivery channel, 9 (25.71\%) are online platforms of traditional newspaper and 5 (14.29\%) are online only. In case of news outlets of language type, bilingual news outlets are leading in using additional delivery channel such as mobile phones, apps, and social media. Five news outlets use mobile phones, 19 breaking news option, 14 apps, and 29 social media. 
$\frac{0}{\frac{0}{0}}$

\begin{tabular}{|c|c|c|c|c|c|}
\hline \multirow{3}{*}{ జ્ય } & 豞 & $a$ & $\stackrel{+}{\sim}$ & $N$ & ఉ \\
\hline & z & $\infty$ & ㄱ & $N$ & $\bar{m}$ \\
\hline & $\stackrel{\mathbb{Z}}{\mathscr{D}}$ & $\neg$ & $n$ & 0 & $\nabla$ \\
\hline \multirow{3}{*}{ 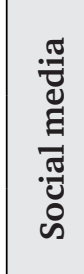 } & 劳 & $a$ & $\stackrel{+}{\sim}$ & $N$ & $\stackrel{\omega}{n}$ \\
\hline & 之 & 0 & $\bullet$ & 0 & $\bullet$ \\
\hline & $\underset{\nu}{\mathscr{D}}$ & $a$ & $\stackrel{\infty}{\sim}$ & N & ลे \\
\hline \multirow{3}{*}{ 号 } & 胥 & $a$ & $\stackrel{+}{\sim}$ & N & $\stackrel{\text { ก }}{\circ}$ \\
\hline & 之 & $\nabla$ & $\stackrel{\sim}{\sim}$ & $N$ & $\vec{N}$ \\
\hline & 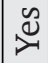 & L & $a$ & 0 & $\underset{\sim}{+}$ \\
\hline \multirow{3}{*}{ 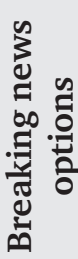 } & 점 & $a$ & $\stackrel{+}{N}$ & N & $\stackrel{\sim}{\oplus}$ \\
\hline & $\stackrel{\circ}{z}$ & $m$ & 드 & $N$ & $\underset{\sim}{\bullet}$ \\
\hline & $\stackrel{\nu}{\beth}$ & $\bullet$ & $\stackrel{m}{=}$ & 0 & $\stackrel{a}{-1}$ \\
\hline \multirow{3}{*}{$\begin{array}{l}\frac{ \pm}{2} \\
\frac{0}{n} \\
\frac{0}{2} \\
z\end{array}$} & 胥 & $a$ & $\stackrel{+}{\sim}$ & $\sim$ & $\stackrel{n}{n}$ \\
\hline & 兄 & $\infty$ & $\stackrel{む}{\checkmark}$ & N & ఉ \\
\hline & $\stackrel{\nu}{2}$ & $\neg$ & 0 & 0 & $\Gamma$ \\
\hline \multirow{3}{*}{ 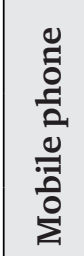 } & $\begin{array}{l}\bar{\pi} \\
\text { ]ే } \\
\text { E }\end{array}$ & $a$ & $\stackrel{+}{\sim}$ & N & $\stackrel{10}{\oplus}$ \\
\hline & 之 & 0 & ฟิ & $N$ & ஓ \\
\hline & $\stackrel{\mathbb{V}}{2}$ & $m$ & $N$ & 0 & เ \\
\hline 总总离 & 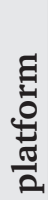 & 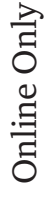 & 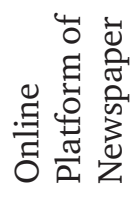 & 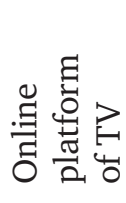 & 胥 \\
\hline
\end{tabular}


0
$\frac{0}{0}$
$\frac{0}{1}$

\begin{tabular}{|c|c|c|c|c|c|}
\hline \multirow{3}{*}{$\underset{\approx}{\mathscr{A}}$} & స్తే & 이 & $\nabla$ & 그 & $\stackrel{\llcorner}{m}$ \\
\hline & Z & 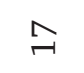 & $\nabla$ & $\stackrel{\circ}{-}$ & $\vec{m}$ \\
\hline & 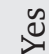 & $m$ & 0 & $\neg$ & ナ \\
\hline \multirow{3}{*}{ 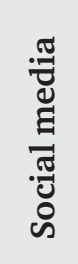 } & ]ే & 요 & $\nabla$ & 다 & $\stackrel{\text { ஸि }}{m}$ \\
\hline & 乙 & L & $r$ & 0 & 6 \\
\hline & $\stackrel{\mathscr{D}}{ }$ & $\stackrel{\sim}{\sim}$ & $m$ & 그 & શે \\
\hline & ] & 이 & $\nabla$ & 가 & $\stackrel{\llcorner}{m}$ \\
\hline & $\stackrel{\circ}{Z}$ & $\underset{\sim}{\stackrel{\sim}{二}}$ & $\neg$ & 0 & $\overrightarrow{\mathrm{N}}$ \\
\hline & $\stackrel{\mathscr{\nu}}{ }$ & 0 & $m$ & L & $\underset{\sqsupset}{ \pm}$ \\
\hline \multirow{3}{*}{ 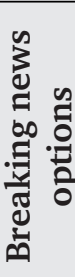 } & స్తే & ㅇ & $\nabla$ & 그 & $\stackrel{\sim}{m}$ \\
\hline & $\stackrel{\circ}{Z}$ & 가 & $N$ & $m$ & $\bullet$ \\
\hline & $\stackrel{\nu}{\nu}$ & $a$ & N & $\infty$ & $\stackrel{a}{-1}$ \\
\hline \multirow{3}{*}{ 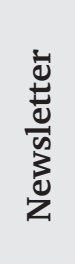 } & 푬 & ㅇ & $\nabla$ & 가 & $\stackrel{\text { ก }}{n}$ \\
\hline & 之 & $\stackrel{\vartheta}{-1}$ & $\nabla$ & 그 & ఉ \\
\hline & $\stackrel{\nu}{\mathscr{\nu}}$ & $\neg$ & 0 & 0 & $\neg$ \\
\hline \multirow{3}{*}{ 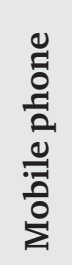 } & 䒿 & 오 & $\nabla$ & 기 & $\stackrel{\omega}{n}$ \\
\hline & $\stackrel{\circ}{Z}$ & $\stackrel{\curvearrowright}{r}$ & $\nabla$ & $\Lambda$ & ○ \\
\hline & 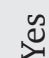 & $\digamma$ & 0 & $\forall$ & م \\
\hline \multicolumn{2}{|c|}{ 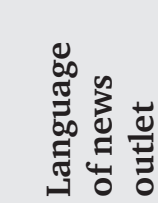 } & 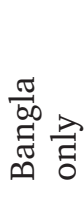 & 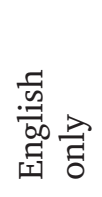 & 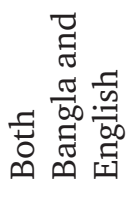 & 䒿 \\
\hline
\end{tabular}




\section{Multimedia option on the homepage}

The term multimedia took its place when computer and the Internet were brought into play in practicing journalism. For the purpose of producing a good story package text, images, audio, video and graphics are used to turn it into a multimedia story. Qasim Akinreti (2007) defines multimedia as a concept which accommodates the processing of text, audio, visuals and graphics into one medium for different people at the same time. Multiple elements include texts, audio, video and graphic eventually complement each other providing a detailed picture enabling audience to comprehend a story with ease.

Bangladeshi news outlets mainly use video as multimedia in their homepage and story. The analysis of data shows (Table 7) that 20 (57.14\%) of them add video to their homepages. Among these outlets, 7 (20.00\%) are online only, $12(34.29 \%)$ are online platforms of traditional newspapers, $10(28.57 \%)$ are Bangla only and 9 (25.71\%) are both Bangla and both Bangla and English. Audio, video, vodcast and podcast are least used in the news outlets. Meanwhile, slide shows and photos are highest used multimedia elements. The results indicate that online only news outlets have to put a lot of effort to capitalize the opportunities brought about by the Internet. 
$\frac{\pi}{0}$

\begin{tabular}{|c|c|c|c|c|c|}
\hline \multirow{3}{*}{ 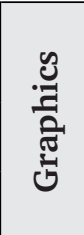 } & 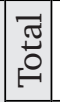 & $a$ & $\stackrel{+}{\sim}$ & $N$ & $\stackrel{m}{m}$ \\
\hline & そ) & $N$ & $\infty$ & $\neg$ & 드 \\
\hline & $\underset{\nu}{\infty}$ & $\Lambda$ & $\stackrel{\bullet}{\sim}$ & $\neg$ & $\stackrel{+}{\sim}$ \\
\hline \multirow{4}{*}{$\begin{array}{l}\text { o } \\
\stackrel{0}{0} \\
\frac{1}{a}\end{array}$} & 점 & $a$ & $\stackrel{ナ}{\sim}$ & N & $\stackrel{m}{m}$ \\
\hline & $\begin{array}{l} \\
Z \\
Z\end{array}$ & 0 & 0 & 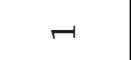 & $-r$ \\
\hline & 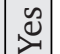 & $a$ & $\stackrel{\leftarrow}{\sim}$ & 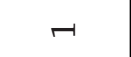 & ఉ \\
\hline & 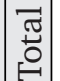 & $a$ & $\stackrel{+}{\sim}$ & $N$ & $\stackrel{\text { m }}{m}$ \\
\hline \multirow{2}{*}{$\frac{0}{-3} \frac{3}{\infty}$} & 이 & N & $\underset{ت}{\Xi}$ & - & $\widehat{ન}$ \\
\hline & $\stackrel{\sim}{2}$ & $\Lambda$ & $\stackrel{\circ}{\circ}$ & 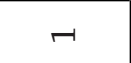 & $\stackrel{\infty}{\sim}$ \\
\hline \multirow{3}{*}{ 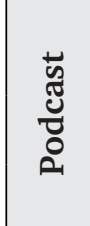 } & 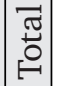 & $a$ & $\stackrel{\star}{\sim}$ & $N$ & $\stackrel{\text { m }}{\text { n }}$ \\
\hline & 号 & $a$ & $\stackrel{\leftarrow}{\sim}$ & $\neg$ & ఉ \\
\hline & $\stackrel{\circlearrowright}{\circlearrowright}$ & 0 & 0 & 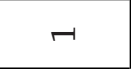 & $-r$ \\
\hline \multirow{3}{*}{ 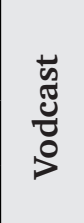 } & 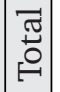 & $a$ & $\stackrel{+}{\sim}$ & $N$ & $\stackrel{\text { m }}{m}$ \\
\hline & $\begin{array}{l} \\
Z \\
\end{array}$ & $a$ & $\stackrel{\sim}{\sim}$ & $\neg$ & ఉ \\
\hline & $\underset{\nu}{\mathscr{D}}$ & 0 & 0 & $\neg$ & $-r$ \\
\hline \multirow{3}{*}{ 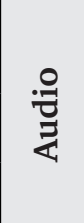 } & 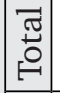 & $a$ & $\stackrel{+}{\sim}$ & N & $\stackrel{\text { m }}{m}$ \\
\hline & 음 & $\Lambda$ & $\stackrel{\leftarrow}{\sim}$ & 기 & ஸे \\
\hline & $\stackrel{\sim}{\stackrel{\sim}{*}}$ & $\sim$ & 0 & - & $m$ \\
\hline \multirow{3}{*}{ 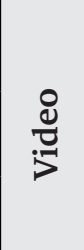 } & 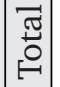 & $a$ & $\stackrel{+}{\sim}$ & $N$ & $\stackrel{\text { M }}{m}$ \\
\hline & ○ & N & $\stackrel{\sim}{\sim}$ & $\neg$ & $\stackrel{10}{\longrightarrow}$ \\
\hline & $\stackrel{\mathscr{D}}{\stackrel{\sim}{*}}$ & $\Lambda$ & $\stackrel{\sim}{\sim}$ & $\neg$ & 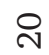 \\
\hline \multicolumn{2}{|c|}{ 疍 } & $\begin{array}{l}\text { Z⿱ } \\
0 \\
0 \\
0 \\
0 \\
0\end{array}$ & 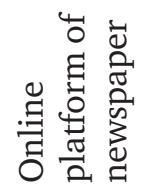 & 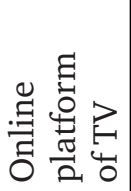 & 점 \\
\hline
\end{tabular}


$\frac{0}{\frac{0}{0}}$

\begin{tabular}{|c|c|c|c|c|c|}
\hline \multirow{3}{*}{ 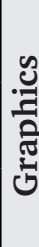 } & 胥 & ㅇ & $\nabla$ & ન & $\stackrel{10}{m}$ \\
\hline & 之 & 0 & 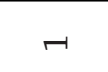 & $\nabla$ & 담 \\
\hline & $\underset{\nu}{\mathscr{\nu}}$ & $\underset{\sim}{ \pm}$ & $m$ & $\Lambda$ & $\stackrel{\nabla}{N}$ \\
\hline \multirow{3}{*}{ 옹 } & 胥 & ণิ & $\nabla$ & 다 & $\stackrel{\varphi}{m}$ \\
\hline & 之 & 0 & 0 & $\sqcap$ & $\Gamma$ \\
\hline & 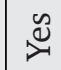 & $\stackrel{\overbrace{}}{\text { ㄱ }}$ & $\nabla$ & $\stackrel{\circ}{ }$ & ఉ \\
\hline \multirow{3}{*}{ 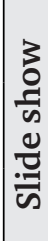 } & 元 & ㅇ & $\nabla$ & 가 & $\stackrel{\text { ก }}{m}$ \\
\hline & 之 & $\infty$ & $\nabla$ & Ln & $\widehat{ન}$ \\
\hline & 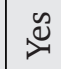 & 오 & 0 & 0 & $\stackrel{\infty}{\cdots}$ \\
\hline \multirow{3}{*}{ 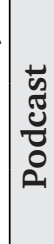 } & 氶 & ㅇ & $\nabla$ & 득 & 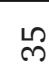 \\
\hline & 之 & ํ & $\nabla$ & $\stackrel{0}{\circ}$ & ఉ \\
\hline & $\stackrel{\circlearrowright}{\circlearrowright}$ & 0 & 0 & 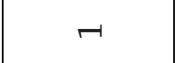 & 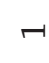 \\
\hline \multirow{3}{*}{ 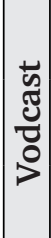 } & స్తే & ণิ & $\nabla$ & 그 & $\stackrel{\nu}{m}$ \\
\hline & $\stackrel{\circ}{z}$ & 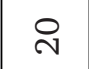 & $\nabla$ & $\stackrel{ }{\rightarrow-1}$ & $\stackrel{ా}{~}$ \\
\hline & $\underset{\nu}{\mathscr{D}}$ & 0 & 0 & - & 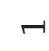 \\
\hline \multirow{3}{*}{ 乲 } & 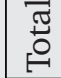 & 오 & $\nabla$ & 가 & $\stackrel{\leftrightarrow}{m}$ \\
\hline & 乙 & $\stackrel{\curvearrowright}{\rightarrow}$ & $\nabla$ & $a$ & ஸे \\
\hline & $\stackrel{\circlearrowright}{\circlearrowright}$ & - & 0 & N & $m$ \\
\hline \multirow{3}{*}{ 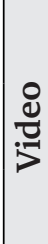 } & 元 & ণ & $\checkmark$ & 금 & $\stackrel{\text { m }}{\circ}$ \\
\hline & 之े & $\stackrel{ }{ }$ & $m$ & N & $\stackrel{10}{\rightarrow}$ \\
\hline & $\underset{\nu}{\mathscr{D}}$ & $\stackrel{\circ}{ }$ & - & $a$ & 尺े \\
\hline \multicolumn{2}{|c|}{ 莺 } & 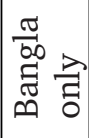 & 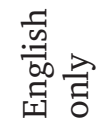 & 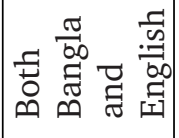 & 㫯 \\
\hline
\end{tabular}




\section{Interactivity}

Interaction generally means mutual exchange, mutual influence, sharing, etc. For media, interaction is multidimensional. It occurs between the media content and audience, media people and its audience. Jens F. Jensen (1998) defined interactivity and interactive media based on four different information patterns transmissional interactivity, consultational interactivity, conversational interactivity and registrational interactivity. All the determinants measure the level of freedom readers enjoy in choosing content from the continuous stream of information. The structural design allows audiences to be engaged directly with the media process. Interactivity provides audiences with the capacity to participate in consumption and production of information. Analysis of data (Table 9 and Table 10) indicates that Bangladeshi news outlets mainly use social media - 33 (94.29\%), print the story - 32 (91.43\%) and comment on the story $26(74.29 \%)$ to allow their audience to interact with the content. Among the news outlets which use social media as an interactive option, $9(25.71 \%)$ are online only and $24(62.86 \%)$ are online platforms. Meanwhile, data in Table 10 show that English language only news outlets (11.43\%) lag far behind Bangla language only (25.71\%) and bilingual (Bangla and English) news outlets (31.43\%) in integrating social media in their story pages. In case of print the story, this figure is $8(22.86 \%)$ for online only and $22(62.86 \%)$ online platforms of traditional newspapers. None of the news outlets have options for providing news tips which indicate that Bangladesh news outlets do not capitalize the power of the insight in their news process. 
$\frac{a}{\frac{0}{0}}$

\begin{tabular}{|c|c|c|c|c|c|}
\hline \multirow{3}{*}{ 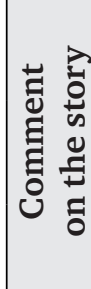 } & 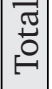 & $a$ & $\stackrel{+}{N}$ & N & $\stackrel{m}{m}$ \\
\hline & z̀ & $\sim$ & م & N & $a$ \\
\hline & $\underset{\nu}{\mathscr{D}}$ & $\curvearrowright$ & $\stackrel{一}{-1}$ & 0 & $\stackrel{\bullet}{*}$ \\
\hline \multirow{3}{*}{ 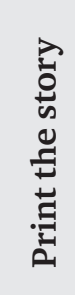 } & 褐 & $a$ & $\stackrel{ \pm}{N}$ & N & $\stackrel{\stackrel{m}{m}}{n}$ \\
\hline & z & - & N & 0 & $m$ \\
\hline & $\underset{\nu}{\infty}$ & $\infty$ & సิ & $N$ & ले \\
\hline \multirow{3}{*}{ 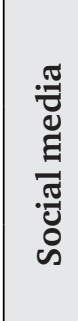 } & $\begin{array}{c}\pi \\
0 \\
0 \\
0\end{array}$ & $a$ & $\stackrel{\leftarrow}{\sim}$ & N & $\stackrel{\llcorner}{m}$ \\
\hline & z & 0 & N & 0 & N \\
\hline & $\stackrel{\mathscr{N}}{\nu}$ & $a$ & ฟิ & N & $m$ \\
\hline \multirow{3}{*}{ 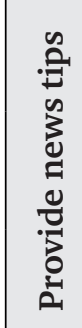 } & 胥 & $a$ & $\stackrel{\leftrightarrow}{\sim}$ & N & $\stackrel{\mathscr{m}}{m}$ \\
\hline & z & $a$ & $\stackrel{+}{N}$ & $N$ & $\stackrel{\stackrel{m}{m}}{2}$ \\
\hline & $\stackrel{\infty}{\circlearrowright}$ & 0 & 0 & 0 & 0 \\
\hline \multirow{3}{*}{ 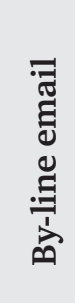 } & $\mid \begin{array}{c}\pi \\
0 \\
0\end{array}$ & $a$ & $\stackrel{\nabla}{N}$ & N & $\stackrel{\llcorner}{m}$ \\
\hline & ○ & $a$ & ฟิ & $N$ & $\stackrel{m}{m}$ \\
\hline & 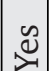 & 0 & N & 0 & $v$ \\
\hline \multicolumn{2}{|c|}{ 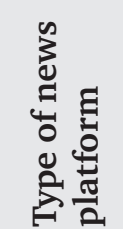 } & 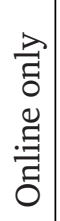 & 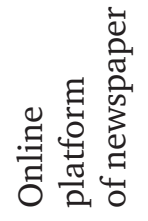 & 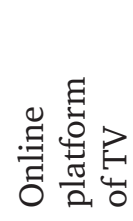 & 풍 \\
\hline
\end{tabular}




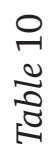

\begin{tabular}{|c|c|c|c|c|c|}
\hline \multirow{3}{*}{ 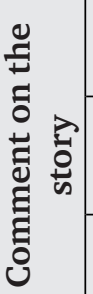 } & 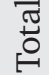 & ণ & $\nabla$ & 닥 & $\stackrel{\text { ก }}{n}$ \\
\hline & 之o & 0 & - & $N$ & $a$ \\
\hline & $\stackrel{\circlearrowright}{\circlearrowright}$ & $\underset{ت}{ \pm}$ & $m$ & $a$ & $\stackrel{\bullet}{v}$ \\
\hline \multirow{3}{*}{ 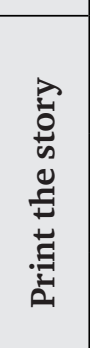 } & 㫯 & ㄱ & $\nabla$ & 가 & ஸn \\
\hline & ㅇ & N & 0 & $r$ & $m$ \\
\hline & 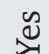 & $\stackrel{\infty}{\sim}$ & $\nabla$ & $\stackrel{ }{\circ}$ & ๗ \\
\hline \multirow{3}{*}{ 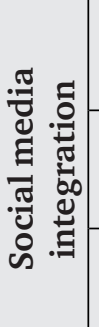 } & స్తే & ㅇ & $\nabla$ & 가 & $\stackrel{\leftrightarrow}{m}$ \\
\hline & 之 & $N$ & 0 & 0 & N \\
\hline & 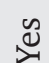 & $\stackrel{\infty}{\sim}$ & $\nabla$ & 거 & $m$ \\
\hline \multirow{3}{*}{ 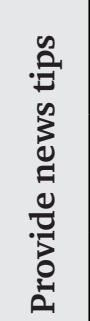 } & त्ञ & 으 & $\forall$ & 닥 & $\stackrel{\text { ๓n }}{m}$ \\
\hline & $\stackrel{\circ}{z}$ & ণ & $\checkmark$ & 가 & $\stackrel{n}{n}$ \\
\hline & 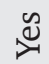 & 0 & 0 & 0 & 0 \\
\hline \multirow{3}{*}{ 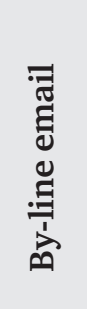 } & तु & 가 & $\nabla$ & 거 & $\stackrel{\text { ஸn }}{n}$ \\
\hline & 운 & ㅇ & $m$ & $\stackrel{ }{-1}$ & $m$ \\
\hline & $\stackrel{d}{\nu}$ & 0 & 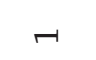 & $r$ & $N$ \\
\hline \multicolumn{2}{|c|}{ 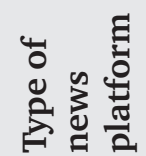 } & 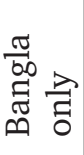 & 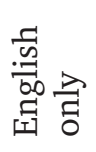 & 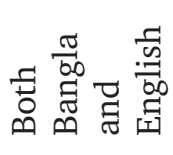 & त्त \\
\hline
\end{tabular}




\section{Conclusion}

Journalism is going through some evolutionary process around the world as well as in Bangladesh. With the help of multiple interactive and convergent technologies, changes, transformations and evolutions are being happening in media ecology and the practices of journalism. With the findings of the study, it can be concluded that news media in Bangladesh have done little to capitalize the immense potentials offered by new information and communication technologies. The results also indicate that the news web-sites did not fully utilize and enhance interactive features in online journalism. The designs of web-sites of sample news outlets are heavily inspired by the design of printed newspapers as they provide very few options for customization, scope of interactivity, embedding of multimedia tools, availability of user-friendly services, and additional delivery channels on their homepages. Most of the Bangladeshi news outlets, which have online presence, seem to be bilingual as majority of the sample outlets provide options for other language edition. The most used additional delivery channels are mobile apps and social media platforms, mainly Facebook.

Online news is an evolving experience. Multiple determinants influence readers' satisfaction in multiple ways. Scope for customization of content, interactivity, multimedia in the story, multimedia next to the story, user-friendly services and hypertext are some of the factors which may satisfy the audience. Among the sample news outlets, text size customization is the only available option that gives readers freedom to increase or decrease the size of the text on their convenience. Meanwhile, social media integration, print the story and comment on the story are on the top available options for interaction in the sample news outlets. On the other hand, video clippings, audio clippings, slide shows, photos and graphics are the most used multimedia elements in the story. In case of user-friendly services, email the story, and rate the story are not present in the news stories of the news outlets. Very few of the sample news outlets embed link to a relevant site in their news stories.

In comparative analysis, it is obvious that online only news outlets in Bangladesh have to do much to be online news media in a truer sense as a majority number of the outlets do not capitalize the immense opportunity for good storytelling brought about by the Internet. Most of the news outlets provide very few web features in their web-sites. Similar, insights are generated about the media type by language (Bangla only, English only and both Bangla and English). It was observed that Bangladeshi news outlets tend to be bilingual (both Bangla and English), and such outlets are a bit ahead of Bangla only and English only ones in catering the opportunities created by the Internet. 
The results yield a novel understanding of online news production, delivery and consumption pattern from Bangladesh context, and create a threshold for future research. But limited sample size is the main weakness of the study, although significant number in the context of Bangladesh. More in-depth insights can be generated if such studies are conducted in broader perspective on larger sample. This research was conducted from the organizational perspective. Future research from audience perspective would offer solid understanding of the evolving new media ecology, the news industry and its future course in Bangladesh.

\section{References}

AKINRETI, Q. (2007). Challenges of online broadcasting in Nigeria. Von Airwaves, Magazine About Broadcasting for Broadcasters.

A list of all registered newspaper \& periodicals by Department of Film and Publication (DFP) (2018). Available from: https://dfp.portal.gov.bd/site/ page/8ce312e2-1148-4be6-afcf-e12e5b6b46a9/List-of-all-registered-newspapersand-periodicals [Accessed 18th September 2018].

ANSTEAD, N. \& O'LOUGHLIN, B. (2014). Social media analysis and public opinion: The 2010 UK general election. Journal of Computer-Mediated Communication, 20(2), pp. 204-220.

BBC Bangla, (January 11, 2018). 2018 applications submitted for online news media. Available from: https://www.bbc.com/bengali/news-42649405 [Accessed 19th September 2018].

BEYERS, H. (2006). What constitutes a good online news site? A comparative analysis of American and European awards. Communications, 31(2). DOI: 10.1515/ commun.2006.014.

BORAH, P. (2014). The hyperlinked world: A look at how the interactions of news frames and hyperlinks influence news credibility and willingness to seek information. Journal of Computer-Mediated Communication, 19(3), pp. 576-590.

CHUNG, D. (2008). Interactive features of online newspapers: Identifying patterns and predicting use of engaged readers. Journal of Computer-Mediated Communication, 13(3), pp. 658-679. DOI: 10.1111/j.1083-6101.2008.00414.x

DE MAEYER, J. (2012). The journalistic hyperlink: Prescriptive discourses about linking in online news. Journalism Practice, 6(5-6), pp. 692-701.

DE MAEYER, J. (2012). Towards a hyperlinked society: A critical review of link studies. New Media \& Society, 15(5), pp. 737-751.

DEUZE, M. (2001). Online journalism: Modeling first generation of news media on the world wide web. First Monday: Peer Reviewed Journal on the Internet, 6(10). Available from: http://ojphi.org/ojs/index.php/fm/article/view/893/802 [Accessed 28th June 2018]. 
JENSEN, J. (1998). Interactivity - tracking a new concept in media and communication studies. Nordicom Review, 19(1), pp. 185-204.

MACNAMARA, J. (2010). Remodelling media: The urgent search for new media business models. Media International Australia, 137, pp. 20-35. DOI: 10.1177/1329878X1013700104

RAFEEQ, A. (2014). Online journalism: A case study of interactivity of mainstream online news websites of the Maldives. The Maldives National Journal of Research, 2(1), pp. 29-47.

RAHMAN, M. (2008). Interactive options in online newspapers of Bangladesh. Pakistan Journal of Social Sciences, 5(6), pp. 620-624. Available from: http:// docsdrive.com/pdfs/medwelljournals/pjssci/2008/620-624.pdf

SALTZIS, K. (2012). Breaking news online: How news stories are updated and maintained around-the-clock. Journalism Practice, 6(5-6), pp. 702-710. DOI: $10.1080 / 17512786.2012 .667274$

SCHULTZ, T. (2006). Interactive options in online journalism: A content analysis of 100 U.S. newspapers. Journal of Computer-Mediated Communication. Available from: https://onlinelibrary.wiley.com/doi/abs/10.1111/j.1083-6101.1999.tb00331.x

SINGER, J. B. (2006). Online journalists: Foundations for research into their changing roles. Journal of Computer-Mediated Communication, 4(1). DOI: 10.1111/ j.1083-6101.1998.tb00088.x

STROUD, N. J., SCACCO, J. M. \& CURRY, A. L. (2015). The presence and use of interactive features on news websites. Digital Journalism, 4(3), pp. 339-358. DOI: 10.1080/21670811.2015.1042982

TANDOC, E. (2014). Breaking news or breaking the newspaper? Print journalists, online journalists and their medium-based loyalties. Plaridel: A Philippine Journal of Communication, Media, and Society, 11(1), pp. 15-34. 